\title{
A comparative clinical study of ondansetron and dexamethasone for prevention of postoperative vomiting in pediatric patients undergoing intra abdominal surgery
}

\author{
Lalit Mohan ${ }^{1}$, Vinit Kumar Thakur ${ }^{2}$, Prakash Kumar Dubey ${ }^{3}$, Harihar Dikshit ${ }^{1}$, \\ Nitish Kumar ${ }^{4}$, Lalit Kumar ${ }^{1 *}$
}

\author{
${ }^{1}$ Department of Pharmacology, \\ ${ }^{2}$ Department of Pediatric \\ Surgery, ${ }^{3}$ Department of \\ Anaesthesiology, ${ }^{4} \mathrm{MBBS}$ \\ student, I.G.I.M.S., Patna, Bihar, \\ India
}

Received: 17 December 2016

Accepted: 07 January 2017

\section{*Correspondence to: \\ Dr. Lalit Kumar, \\ Email: lalit2181@gmail.com}

Copyright: (C) the author(s), publisher and licensee Medip Academy. This is an openaccess article distributed under the terms of the Creative Commons Attribution NonCommercial License, which permits unrestricted noncommercial use, distribution, and reproduction in any medium, provided the original work is properly cited.

\begin{abstract}
Background: This study aimed to compare the efficacy of intravenous ondansetron and dexamethasone for prevention of post-operative vomiting in pediatric patients whom underwent intra-abdominal surgery at Indira Gandhi institute of medical sciences, Patna.

Methods: A total of 40 eligible patients were included in the study. There were 20 patients in group 1 whom received i.v ondansetron $(0.1 \mathrm{mg} / \mathrm{kg})$, and 20 patients in group 2 received i.v Dexamethasone $(1 \mathrm{mg} / \mathrm{kg})$ one minute prior to the induction of anaesthesia. Episodes of postoperative vomiting within first 24 hours of anaesthesia and thereafter in postoperative ward at different intervals was observed and recorded.

Results: Complete control of PONV (no emesis, no rescue treatment for 24 hours after administration of study agent) was achieved in $40 \%$ of cases in group I, in $42.25 \%$ of cases in group II, mild PONV was achieved in $7.5 \%$ of cases in group I, in $5.0 \%$ of cases in group II, moderate PONV was achieved in $2.5 \%$ of cases in group I, in $2.5 \%$ of cases in group II, and severe PONV was not found in any of the two group. There was no statistically significant difference between the groups1and 2 in terms of baseline characteristics and postoperative managements. Frequency of postoperative nausea and vomiting experiences were similar between the groups $(\mathrm{p}>0.05)$.

Conclusions: Single dose ondansetron $0.1 \mathrm{mg} / \mathrm{kg}$ and dexamethasone 0.5 $\mathrm{mg} / \mathrm{kg}$, given intravenously are equally effective agents for the control of PONV. Both drugs for the same indication do not seem to increase the antiemetic efficacy.
\end{abstract}

Keywords: Dexamethasone, General anaesthesia, Post operative nausea and vomiting (PONV), Pediatric surgery, Ondansetron

\section{INTRODUCTION}

The most common and distressing symptoms, which follow anaesthesia and surgery, are emesis and pain. Many patients find it more troublesome than the postoperative pain itself. Compared to adults, paediatric patients are more likely to develop postoperative nausea and vomiting, the incidence of which ranges from $8.9 \%$ to $42 \%{ }^{1}$ Studies in children are often limited to data on vomiting only and not nausea. The syndrome of nausea, retching and vomiting is known as 'sickness' and each part of it can be distinguished as a separate entity. ${ }^{2}$ PONV (postoperative nausea and vomiting) has been characterized as the "big little problem" by Kapur, and has been common complication for both in patients and out patients undergoing virtually all types of surgical procedures. $^{3}$

The consequences of PONV are physical, surgical and anaesthetic complications for patients as well as financial implications for the hospitals or institutions, and it is one of the most common reasons for poor patient satisfaction rating in the postoperative period. ${ }^{4,5}$ It is postulated that ondansetron and other 5-HT3 receptor antagonists exerts its antiemetic action both peripherally (vagus and sympathetic nerves) and centrally (CTZ and vomiting 
center) by blocking stimulation of serotonin receptors (Pisters and Kris). Serotonin Receptor Antagonists (SRA) like Ondansetron has a proven efficacy and is recommended as a prophylactic antiemetic at the time of induction of anesthesia. ${ }^{6}$ The precise mechanism of action of Dexamethasone is unknown but it has been proposed that the antiemetic properties arise due to activation of glucocorticoid receptors in the medulla, or by inhibiting central production of prostaglandins or inhibiting the release of endogenous opioids. ${ }^{7,8}$

Here, the experiment is designed to find the better efficacious drug for prophylaxis against post operative vomiting undergoing intra abdominal surgery.

\section{Objective}

Ondansetron and Dexamethasone have been observed to decrease the incidence of vomiting by children after general anaesthesia. So, Doctors are always facing difficulties to select one drug for the prophylaxis against Post operative nausea and vomiting.

The present study was designed to compare the clinical efficacy of intravenous titrated dose of Ondansetron and Dexamethasone for prevention of vomiting after Intra Abdominal Surgery in pediatric age group under general anesthesia.

\section{METHODS}

This study was carried out in the Departments of pharmacology, pediatric and anesthesiology, Indira Gandhi Institute of Medical Sciences, Patna. Approval from institutional ethics committee was obtained to conduct the study. Prior to initiation of study, written informed consent from the patient/legal guardian of the patient was obtained after full explanation of elements contained in the research protocol. A total number of 40 patients were included in the study.

\section{Study design}

This study was double blind with Randomized controlled design. The Study planned for intra abdominal surgery under general anaesthesia.

A standardized protocol for general anesthesia was followed for all patients. Those patients in whom dexamethasone was administered for some other reason were not included in the study.

Patients were randomly divided into two categories:

(1). Group I (O): Patients who had received intravenous Ondansetron $0.1 \mathrm{mg} / \mathrm{kg}$ body weight in $2 \mathrm{ml}$ of normal saline.

(2). Group II (D): Patients who had received intravenous Dexamethasone $1 \mathrm{mg} / \mathrm{kg}$ body Weight in $2 \mathrm{ml}$ of normal saline.
The study medications were prepared by the technician in identical syringes and in equal volume to make the study double blind. Neither the patient nor the observer was aware of the medication received by the patient.

Patients in both groups received ondansetron and dexamethasone, diluted in $2 \mathrm{ml}$ normal saline i.v. slowly over 30 second, one minute before induction of anaesthesia. Postoperative monitoring of patients was started. Episodes of postoperative vomiting within first 24 hours of anaesthesia and thereafter in postoperative ward at different intervals was observed and recorded.

Complete response of prophylactic antiemetic was defined as no post operative vomiting and no need for rescue antiemetic medication 24 hours after anesthesia.

The severity of PONV was graded as follows: ${ }^{9}$

1. No PONV: Absence of any emesis or nausea.

2. Mild PONV: Patients having only mild nausea, or one emetic episode or nausea lasting for less than 10 minutes and where no antiemetic is required.

3. Moderate PONV: Patient has 1-2 emetic episodes or moderate to severe nausea and antiemetic therapy is required.

4. Severe PONV: Patient has more than 2 emetic episodes or is nauseated more than twice and more than one antiemetic required.

Severity of postoperative vomiting was evaluated by total score after 24 hours. Occurrence of incidence of any adverse effects supposed to be due to Ondansetron and dexamethasone was looked for. The rescue antiemetic (metoclopromide 10mg) i.v., were given, if patient needed during study period.

All the observed parameters and results were carefully recorded and analyzed statistically. Statistical analysis of data was done using arithmetic mean and standard deviation. Comparison of results among two groups was done using Chi-square test through EPSS software.

\section{RESULTS}

A total of 40 eligible patients were included in the study. There were 20 patients in group 1 whom received i.v ondansetron, and 20 patients in group 2 received i.v Dexamethasone treatment. The treatment groups were comparable (Table 1). Complete control of PONV (no emesis, no rescue treatment for 24 hours after administration of study agent) was achieved in $40 \%$ of cases in group I, in $42.25 \%$ of cases in group II, mild PONV was achieved in $7.5 \%$ of cases in group I, in $5.0 \%$ of cases in group II, moderate PONV was achieved in $2.5 \%$ of cases in group I, in $2.5 \%$ of cases in group II, and severe PONV was not found in any of the two group. There was no statistically significant difference between the groups 1 and 2 in terms of baseline characteristics and postoperative managements. Frequency of postoperative nausea and vomiting experiences were similar between the groups $(\mathrm{p}>0.05)$. 
Table 1: Total PONV Score comparison group 1 and group 2.

\begin{tabular}{|c|c|c|c|c|c|c|}
\hline \multirow{2}{*}{ Group } & \multirow{2}{*}{ Drug } & & \multicolumn{3}{|c|}{ Total PONV } & \multirow[t]{2}{*}{ Total } \\
\hline & & & No PONV & Mild PONV & Moderate PONV & \\
\hline \multirow[t]{2}{*}{1} & Ondansetron & Count & 16 & 3 & 1 & 20 \\
\hline & & $\%$ of Total & $40.0 \%$ & $7.5 \%$ & $2.5 \%$ & $50.0 \%$ \\
\hline \multirow[t]{4}{*}{2} & Dexamethasone & Count & 17 & 2 & 1 & 20 \\
\hline & \multirow{3}{*}{ Total } & $\%$ of Total & $42.5 \%$ & $5.0 \%$ & $2.5 \%$ & $50.0 \%$ \\
\hline & & Count & 33 & 5 & 2 & 40 \\
\hline & & $\%$ of Total & $82.5 \%$ & $12.5 \%$ & $5.0 \%$ & $100.0 \%$ \\
\hline
\end{tabular}

\section{DISCUSSION}

This randomized, prospective, double blind study demonstrated that intra abdominal surgery in paediatric patients using $0.1 \mathrm{mg} / \mathrm{kg}$ intravenous ondansetron as a single agent for the control of PONV is as effective as 0.5 $\mathrm{mg} / \mathrm{kg}$ intravenous dexamethasone.

Ondansetron is 5-HT3 receptor antagonist, which is effective in preventing PONV. The effectiveness of intravenous (i.v.) ondansetron as prophylactic postoperative antiemetic was evaluated by McKenzie and colleagues in dose ranging study. ${ }^{10}$

Dexamethasone was first reported as an antiemetic in patients receiving cancer chemotherapy in $1981 .{ }^{11}$ The exact mechanism of antiemetic action of dexamethasone is not known. However, there have been some suggestions, such as central or peripheral inhibition of production or secretion of serotonin, central inhibition of the synthesis of prostaglandins or changes in permeability of the blood-brain barrier to serum proteins. ${ }^{12,13}$

There are some studies having similar type of result. A study done in patients for checking "antiemetic effects of dexamethasone and ondansetron combination during caesarean sections under spinal anaesthesia" found similar result. As per the study single dose $4 \mathrm{mg}$ ondansetron, $8 \mathrm{mg}$ dexamethasone, or combined use of $8 \mathrm{mg}$ dexamethasone $+4 \mathrm{mg}$ ondansetron, given intravenously is all effective agents for the control of post delivery nausea and vomiting. Combined use of dexamethasone and ondansetron for the same indication does not seem to increase the antiemetic efficacy. ${ }^{14}$ Another Study "does the added benefit of ondansetron over dexamethasone, to control post-operative nausea and vomiting, justify the added cost in patients undergoing tonsillectomy and adenotonsillectomy?" found dexamethasone was equally effective in controlling PONV in tonsillectomy and adenotonsillectomy patients. The improved benefit of using ondansetron over dexamethasone, on a regular basis, does not justify the added cost. ${ }^{15}$

However, there are some studies showing combination therapy is superior to single drug prophylaxis for PONV.
Like a study "comparison of the antiemetic effect of ramosetron with the combination of dexamethasone and ondansetron in middle ear surgery: A double-blind, randomized clinical study" illustrating that the combination of dexamethasone and ondansetron is superior to ramosetron for prevention of PONV after middle ear surgery. ${ }^{16}$

However, there are some studies which say that in some cases routine prophylaxis might be unnecessary. Like a study "dexamethasone versus ondansetron in combination with dexamethasone for the prophylaxis of postoperative vomiting in pediatric outpatients: a doubleblind, randomized, placebo-controlled clinical trial." In this case the prophylactic use of antiemetic drugs failed to reduce the incidence of POV in pediatric outpatient surgery with a low emetic potential; therefore, routine prophylaxis may be unnecessary. ${ }^{1}$

\section{CONCLUSION}

Single dose ondansetron $0.1 \mathrm{mg} / \mathrm{kg}$ and dexamethasone $0.5 \mathrm{mg} / \mathrm{kg}$, given intravenously are equally effective agents for the control of PONV. Both drugs for the same indication do not seem to increase the antiemetic efficacy.

As both the drug have equal efficacy for the same indication. So, by considering the cost effective treatment, Doctor should prescribe relatively cheaper drug to the patients.

\section{ACKNOWLEDGEMENTS}

The paper is derived from short term student project of ICMR and Student received award for the same.

Funding: No funding sources

Conflict of interest: None declared

Ethical approval: The study was approved by the Institutional Ethics Committee

\section{REFERENCES}

1. de Orange FA, Marques J, Flores M, Borges PS. Dexamethasone versus ondansetron in combination 
with dexamethasone for the prophylaxis of postoperative vomiting in pediatric outpatients: a double-blind, randomized, placebo-controlled clinical trial. Paediatr Anaesth. 2012;22(9):890-96.

2. Knappe MR, Beecher HK. Post anaesthetic nausea, vomiting and retching: evaluation of antiemetic drugs dimenhydrinate, chlorpromazine and pentobarbital sodium. Journal of American Medical Association. 1956;160:376-85.

3. Kapur PA. The big "little problem". Anesth Analg. 1991;73:243-5.

4. White PF, Watcha MF. Post operative nausea and vomiting: Its etiology and treatment. Anaesthesiology. 1992;77:162-84.

5. Mytes PS, Williams DL, Hendrata M. Patient satisfaction after anaesthesia and surgery: results of a prospective survey of 10811 patients. Br J Anaesth. 2000;84:6-10.

6. Shams TMA, Nahla E, Raga EI. Prophylactic small doses of mixture of 5-HT3 receptor antagonists and dexamethasone on PONV and adverse effects. EJICT. 2012;1:132-8.

7. Ho CM, Ho ST, Wang JJ, Tsai SK, Chai CY. Dexamethasone has a central antiemetic mechanism in decerebrated cats. Anesth Analg. 2004;99(3):7349.

8. Holte $\mathrm{K}$, Kehlet $\mathrm{H}$. Perioperative single-dose glucocorticoid administration: pathophysiologic effects and clinical implications. J Am Coll Surg. 2002;195:694-712.

9. Wilson EB, Bass CS, Abrameit W, Roberson R, Smith RW. Metoclopramide versus ondansetron in prophylaxis of nausea and vomiting for laparoscopic cholecystectomy. Am J Surg. 2001;181:138-41.

10. McKenzie R, Kovac A, O'Connor T, Duncalf D, Angel J, Gratz 1, et al. Comparison of ondansetron versus placebo to prevent postoperative nausea and vomiting in women undergoing journal of the College of Physicians and Surgeons Pakistan;
2008;18(5):265-9. Ambulatory gynecologic surgery. Anesthesiology. 1993;78:21-8.

11. Aapro MS, Alberts DS. Dexamethasone as an antiemetic in patients treated with cisplatin. N Engl J Med. 1981;305:520.

12. Fredrikson M, Hursti T, Fürst CJ, Steineck G, Börjeson S, Wikblom $\mathrm{M}$, et al.Nausea in cancer chemotherapy is inversely related to urinary cortisol excretion. Br J Cancer. 1992;65:779-80.

13. Livera P, Trojano M, Simone IL, Zimatore GB, Logroscino GC, Pisicchio L, et al. Acute changes in blood-CSF barrier perselectivity to serum protein after intrathecal methotrexate and CNS irradiation. J Neurol. 1985;231:336-9.

14. Demirhan A, Tekelioglu YU, Akkaya A, Ozlu T, Yildiz I, Bayir $\mathrm{H}$, et al. Antiemetic effects of dexamethasone and ondansetron combination during caesarean sections under spinal anaesthesia. Afr Health Sci. 2013;13(2):475-82.

15. Rabbani MZ, Khan MN, Qureshi R, Zubair M, Pervez MB. Does the added benefit of ondansetron over dexamethasone, to control post-operative nausea and vomiting, justify the added cost in patients undergoing tonsillectomy and adenotonsillectomy? J Pak Med Assoc. 2010;60(7):559-61.

16. Desai S, Santosh MCB, Annigeri R, Santoshi VB, Rao R. Comparison of the antiemetic effect of ramosetron with the combination of dexamethasone and ondansetron in middle ear surgery: A doubleblind, randomized clinical study. SJA. 2013;7(3):254-8.

Cite this article as: Mohan L, Thakur VK, Dubey PK, Dikshit H, Kumar N, Kumar L. A comparative clinical study of ondansetron and dexamethasone for prevention of postoperative vomiting in pediatric patients undergoing intra abdominal surgery. Int J Basic Clin Pharmacol 2017;6:462-5. 